\title{
JOSÉ BONIFÁCIO, O ECONOMISTA (*).
}

Quando todo o País comemora o segundo centenário do nascimento dêste seu filho - ilustre e bravo - a nós nos parece que a melhor forma de expressar a nossa gratidão àquêle que foi chamado de "verdadeiro pai da pátria" será confessarmos a nós mesmos que José Bonifácio quis, como base para um Brasil verdadeiramente independente, as reformas que nós ainda não realizamos ou que hesitamos em realizar.

Chegando ao Brasil depois de 36 anos de ausência, veio encontrar a antiga colônia elevada à categoria de reino, sede da monarquia portuguêsa e possuindo já todo o aparelhamento dos serviços públicos indispensáveis - secretarias, tribunais, repartições, estabelecimentos de ensino. Era a fachada de um nôvo Estado que se construira, uma vida nova que se desenvolvera ao impulso das medidas de ordem econômica tomadas por Dom João - abertura dos portos brasileiros ao comércio universal e a revogação do alvará que proibira a indústria no Brasil.

Ao estudioso Andrada não satisfazia essa aparência de Estado organizado. Reconhecia o verdadeiro estágio de desenvolvimento do País, com mais de um milhão de escravos numa população total inferior talvez a quatro milhões de habitantes, num Brasil mal saído da opressão colonial, sem escolas, sem universidades, em que até 15 anos atrás não se admitia a existência de um prelo ou de um jornal.

$\mathrm{Na}$ luta que travou por tornar a sua pátria independente, não inspiraram a José Bonifácio apenas sentimentos. Razões de estadista, de sociólogo e de economista o animavam. Assim é que no Manifesto que redigiu para o Príncipe Regente dirigir aos governos e nações amigas, um mês antes da proclamação da independência, dizia Bonifácio: "Sempre quiseram os europeus conservar êste rico país na mais dura e triste dependência da metrópole, porque julgavam ser-lhe necessário estancar ou pelo menos empobrecer a fonte perene de suas riquezas".

(*). - Palestra proferida na Rádio Atlântica, de Santos, em 4 de junho de 1963 (Nota da Redação). 
E, se ao lutar por um Brasil independente, alinhava razões de ordem econômica, o Patriarca propugnou também por reformas que fôssem capazes de alicerçar em sólidas bases econômicas essa mesma independência.

Assim é que, já como membro da Junta Provisória de Govêrno de São Paulo, já como deputado à Assembléia Constituinte ou como Ministro do Império, sugeriu, propôs e luton por medidas que, à época, fizeram-no parecer a muitos como um revolucionário louco que tinha planos de extinguir o tráfico negreiro, abolir a escravidão, mudar a capital para o interior, confiscar terras improdutivas, distribuir terras a quem as quisesse trabalhar, sendo por isso acusado de querer subverter todo o regime de trabalho e tôda a economia do Brasil.

Devemos lembrar, de início, as instruções que deu, no Govêrno Provisório de São Paulo, aos Deputados da Província às Côrtes portuguêsas para se conduzirem em relação aos negócios do Brasil. Foi nessa oportunidade que propôs a interiorização da capital do País, sòmente agora tornada realidade. Dizia o então vice-presidente da Junta Provisória de Govêrno de São Paulo: "Parece-nos também muito útil que se levante uma cidade central no interior do Brasil para assento da Côrte ou Regência...". Atente-se para os motivos de ordem econômica que José Bonifácio apresentava para essa transferência: "Dêste modo se chama para as províncias centrais o excesso da povoação vadia das cidades marítimas e mercantes: Desta côrte central dever-se-ão logo abrir estradas para as diversas províncias e portos de mar, para que se comuniquem e circulem, com tôda a prontidão, as ordens do Govêrno e se favoreça por elas o comércio interno do vasto Império do Brasil".

Numa hora em que desperta o mais aceso debate na $\mathrm{Na}-$ ção o problema do pagamento pelas terras que venham a ser desapropriadas numa reforma agrária, merecem meditação as palavras de José Bonifácio, escritas há um século e meio, propondo que "tôdas as terras que foram doadas por sesmaria e não se acharem cultivadas entrem outra vez na massa dos bens nacionais". Queria José Bonifácio não sòmente que se confiscassem as terras improdutivas, como também que aos seus donos se deixasse sòmente "meia légua quadrada, quando muito", com a condição de começarem logo a cultivá-las "em-tempo determinado, que parecer justo...". E não se limitava a isto. Queria também a distribuição das terras: "Que haja uma caixa ou cofre em que se recolha o produto da ven- 
da destas terras, que será empregado em favorecer a colonização de europeus, pobres, índios, mulatos e negros forros, a quem se darão de sesmaria pequenas porções de terrenos para cultivarem e se estabelecerem".

Devemos salientar que, numa época em que a sociologia e a economia não eram disciplinas ensinadas nas escolas, José Bonifácio, ao dirigir-se aos deputados constituintes do Império a respeito do problema da escravatura, procurou convencê-los mais com argumentos de ordem econômica que morais.

Eis o que dizia o deputado por São Paulo, mais de meio século antes de os brasileiros libertarem os seus escravos: "A introdução de novos africanos no Brasil não aumenta a nossa população e só serve de obstar a nossa indústria. Para provar a primeira tese bastará ver com atenção o censo de cinco ou seis anos passados, e ver-se-á que apesar de entrarem no Brasil, perto de quarenta mil escravos anualmente, o aumento desta classe é nulo ou de mui pouca monta... e todavia custaram imensos cabedais que se perderam para sempre e que nem sequer pagará o juro do dinheiro empregado. Para provar a segunda tese, que a escravatura deve obstar a nossa indústria, basta lembrar que os senhores que possuem escravos vivem em grandíssima parte da inércia, pois não se vêm precisados a aperfeiçoar sua indústria ou melhorar sua lavoura". Preocupava-lhe o emperramento ao progresso econômico que significava a sociedade escravagista: "As máqúinas, que poupam os braços, pela abundância extrema de escravos nas povoações grandes, sã́o desprezadas". E não se conformava tampouco com a baixa rentabilidade do capital empregado numa lavoura tratada por escravos. E argumentava: "A lavoura do Brasil, feita por escravos boçais e preguiçosos' não dá os lucros com que homens ignorantes e fanáticos se iludem. Se calcularmos o custo atual do terreno, os capitais empregados nos escravos que o devem cultivar, o valor dos instrumentos rurais com que deve trabalhar cada um dêstes escravos, sustento e vestuário, moléstias reais e afetadas, as mortes numerosas, as repetidas fugas, claro fica que o lucro da lavoura deve ser muito pequeno no Brasil, ainda apesar da prodigiosa fertilidade de suas terras".

No combate que sustentou contra a escravatura, José Bonifácio expôs e condenou todos os males econômicos e políticos do regime do trabalho servil. Os senhores de engenho e fazendeiros - que o já tinham por inimigo desde que propusera o confisco das terras improdutivas - não o quiseram ouvir. 
Dirigentes de uma classe que exercia o domínio do Brasil, procuraram anular a ação do Ministro da Independência. Ao seu lado tinham os poderosos e ricos comerciantes portuguêses que exerciam o tráfico de escravos. E, como não poderia deixar de acontecer, aliados também de seus encarniçados oponentes foram os que exerciam atividades monopolísticas na economia brasileira.

No projeto de Constituição apresentado à Assembléia Constituinte em setembro de 1823, José Bonifácio inspirara seu irmão Antônio Carlos a inscrever princípio que só agora se procura transformar em realidade, através da lei que recentemente criou a Comissão Administrativa de Defesa Econômica. Dizia o artigo 19 dêsste projeto de Constituição: "Não se estabelecerão novos monopólios. Antes as leis cuidarão em acabar, com prudência, os que ainda existem".

Não somos os primeiros a chamar a atenção para a preocupação de José Bonifácio com as questões da economia brasileira. Joaquim Nabuco, que sugeriu o tema em relação ao problema da escravatura, adianta que talvez quem empreenda com mais profundidade o estudo das posições assumidas pelo Andrada venha a descobrir que as suas idéias explicam em boa parte o ostracismo a que se viu condenado.

Porque se opôs a interêsses poderosos pensando apenas numa agricultura racional e numa indústria que poderia crescer, desde que existissem assalariados para nela trabalharem e para adquirirem seus produtos, José Bonifácio sofreu uma oposição encarniçada. Quando na Oposição, chamaram-no de louco. Quando no Govêrno, de désposta. Embora fizesse êle questão de dizer que "nas reformas deve haver muita prudência: se conhecer o verdadeiro estado dos tempos, o que êstes sofrem que se reforme, e o que deve ficar do antigo".

José Bonifácio, filósofo, botânico, mineralogista, estadista e poeta, foi também economista, na medida em que entendermos como tal sua preocupação pela realidade econômica do País e o estudo dessa realidade para o melhor eqüacionamento possível dos problemas nacionais em função do bem-comum. Esste o traço fundamental de tôda a vida e de tôdas as atividades de José Bonifácio. O conceito que dêle poderíamos fazer de economista se enquadra bem na citação de Camões: "A ciência militar prestante não se aprende senhor...

Ao economista José Bonifácio, prestemos nossas homenagens.

VALENTIM FERNANDES BOUÇAS 